\title{
An Effective Supervision Model of a Standard Clause for Consumer Protection in the Business Transactions
}

\author{
M. Syamsudin \\ Faculty of Law, Universitas Islam Indonesia \\ Jln. Tamansiswa No. 158, Yogyakarta 55151, Indonesia \\ Tel./Fax: +62-274-377043 E-mail: syamsudin.jawandi@gmail.com

\section{Bekti Hendrie Anto} \\ Faculty of Economics, Universitas Islam Indonesia \\ Jln. Ring Road Utara, Depok, Sleman, Yogyakarta 55281, Indonesia \\ Tel./Fax:+62-274-881546E-mail: mohanto96@gmail.com \\ M. Nur Laili Dwi Kurniyanto \\ Faculty of Law, Universitas Islam Indonesia \\ Jln. Tamansiswa No. 158, Yogyakarta 55151, Indonesia \\ Tel./Fax: +62-274-377043 E-mail: lailics93@gmail.com

\section{Intan Puspitasari} \\ Faculty of Law, Universitas Islam Indonesia \\ Jln. Tamansiswa No. 158, Yogyakarta 55151, Indonesia \\ Tel./Fax:+62-274-377043 E-mail: intanpuspitasari1406@gmail.com \\ Submitted: Jan 23, 2017; Reviewed: Mar 25, 2017; Accepted: Mar 28, 2017
}

\begin{abstract}
This research aims to form an effective supervision model of a standard clause to protect consumer's rights and interests. This study answers the questions the effectiveness of a standard clause supervision carried out by Otoritas Jasa Keuangan [Financial Services Authority (OJK)] and Badan Penyelesaian Sengketa Konsumen [Consumer Dispute Settlement Agency (BPSK)]; effective supervision model of a standard clause which can protect the rights and interest of the consumer. The object of this study are OJK and BPSK as a supervision of a standard clause. The result of this research shows that the supervision of standard clause done by those institutions has not been effective yet, this caused by several factors to wit the weakness of implementing regulation in terms of supervision, unclear supervision mechanism, the weakness of socialization related to the rules of standard clause towards business actors, and other weakness and obstacles faced by both institutions. The effective supervision model of standard clause is being formed that based on five points, namely: (1) the needs of institution/agency reformation who authorize to do supervision of standard clause; (2) the needs to determine the scope of duty and authority of standard clause supervision institution; (3) the needs of determination of material range about standard clause subjected to supervision which comprises: the content, the form, the position and the expression; (4) the needs of precise mechanism of standard clause supervision conducted by supervision institution; (5) the needs of following up the supervision results, especially to the business actors who break the standard clause rules.
\end{abstract}

Keywords: Consumer Protection; Standard Clause; Supervision Model

DOI: 10.20956/halrev.v3i1.763 


\section{INTRODUCTION}

This research idea came up from the issues related to the supervision duty and authority of Consumer Dispute Agency (BPSK) and Financial Services Authority (OJK) towards a standard clause. The issues of this research come from the notion that the supervision conducted by both institutions has not been effective, even it is ineffective, and many problems occur either from the regulation aspect or the practice in the field. From the regulation point, the standard clause supervision has not been supported by the sufficient implementation rules from both institutions. There are many vacuum of regulations resulted in the legal uncertainty of both institutions. Meanwhile in the aspect of the practice in the field shows numbers of weaknesses especially from the aspect of essential role and function of both institutions in doing supervision towards standard clause. Therefore, in practice show symptoms that the role of BPSK and OJK very weak in conducting the supervision of a standard clause done by business actors that result consumer loss.

The supervision of a standard clause is the elaboration of the preventive function over the feasibility of standard clause violation by the business actor. ${ }^{1}$ Article 52 of Act Number 9 Year 1999 concerning Consumer Protection (Consumer Protection Act) has firmly stated that one of the authorities given to BPSK is to do supervision of standard clause. Thus, BPSK has supervision authority towards the inclusion of standard clause which should be

David M.L. Tobing. (2015). Klausula Baku: Paradoks dalam Penegakan Hukum Perlindungan Konsumen. (Dissertation). Jakarta: Postgraduate School, Universitas Indonesia, p. 73. by Article 18 of Consumer Protection Act. The provision regulates the procedures of standard clause inclusion towards business actors, as follow:

(1) In offering the goods and/or services for trading, the entrepreneurs are prohibited from making or including a standard clause on each document and/ or agreement if: (a) it states the transfer of the entrepreneurs, responsibility; (b) it states that the entrepreneurs reserve the right to refuse to receive back the goods already purchased by the consumer; (c) it states that the entrepreneurs reserve the right to refuse to refund for the goods and/or services already purchased by the consumer; (d) it states that it gives the authority to the entrepreneurs from the consumers to carry out directly or indirectly all unilateral actions with regards to the goods purchased on installer the consumers; (e) it regulates concerning the authentication to forfeit the use of the goods or the benefits of the services purchased by the consumers; (f) it gives rights to the entrepreneurs to reduce the benefits of the services or reduce the properties of the consumers as the object of services trading; (g) it states that the consumers are subject to the new regulation, additional regulation, continued regulation and/or continuous change of regulation made unilaterally by entrepreneurs during the period the consumers are using the services they purchased; (h) it states that the consumers give authority to the entrepreneurs to impose mortgage, 
pledge or guarantee against the goods purchased on installment by the consumer.

(2) Entrepreneurs are prohibited from including a standard clause at the place or in the form which is hard to see or cannot be read clearly, or under the statement which is difficult to understand:

(3) Each standard clause stipulated unilaterally by the entrepreneur in the document or contract which falls under the provisions as intended by Section 1 and Section 2 above shall be declared invalid by operation of law.

(4) Entrepreneurs are obligated to adjust the standard clause which contravenes this law.

The provision of article 18 of Consumer Protection Act which covers the prohibition of inclusion of standard clauses basically can be classified into four sections: (a) the prohibition of certain standard clause in the document and/or agreement; (b) the standard to include standard clause in the agreement; (c) the consequence of standard clause inclusion contradict to the Consumer Protection Act; (d) the obligation of business actor to obey the rules of clauses under Consumer Protection Act. ${ }^{2}$

The supervision conducted by BPSK towards the implementation of Article 18 of Consumer Protection Act includes the supervision of standard clauses formed by State-Owned Enterprises, District-Owned Enterprises, private companies, government or private banks, financial institutions, etc. ${ }^{3}$ Ibid. p. 61.

Susanti Adi Nugroho. (2011). Proses Penyelesaian Sengketa Konsumen Ditinjau dari Hukum Acara serta Kendala Implementasinya. Jakarta: Kencana. p. 84.
Therefore, any aspect governing about standard clause shall subject to the domain of BPSK supervision.

In conducting the standard clause supervision, according to Article 9 section (1) of Decision of Industrial and Trade Ministry Republic of Indonesia Number 350/MPP/ Kep/12/2001 concerning the Implementation of Duty and Authority of BPSK, BPSK shall act actively in doing its duty and authority. Therefore, the supervision of standard clause inclusion shall be done with or without complaint from the consumer. ${ }^{4}$

Besides BPSK, the Act Number 21 Year 2011 concerning Financial Services Authority (FSA Act) gives unequivocal authority to OJK. The supervision of standard clause is expressly in the field of financial services. This institution then takes over the whole function, duty, and authority of regulating and supervising financial services activity in the capital market sector, insurance, pension fund, finance institution, and other monetary institution, and thus becomes the authority of OJK. ${ }^{5}$ The establishment of this institution affects the legal protection of consumer in the field of financial services, among others, the supervision of standard clause, dispute settlement and enforcement of consumer protection in the field of financial services previously under the duty and authority of BPSK.

The alteration of legal protection towards consumer in the field of financial services is reaffirmed by OJK itself through the enactment of Regulation Number 1/ POJK.07/2013 concerning the Consumer David M.L Tobing, Op.Cit. p. 66. Inda Rahardyan. (2014). Hukum Pasar Modal Indonesia. Pengawasan Pasar Modal Pasca Terbentuknya Otoritas Jasa Keuangan. Yogyakarta: UII Press. p. 113. 
Protection in the Sector of Financial Services.

This regulation is an instrument formed to perform the provision under Article 31 of FSA Act. More specifically, in regards to the standard clause, in 2014 OJK has established Circular Letter Number 13/SEOJK.07/2014 regarding Standard Agreement (SACL). According to the Circular Letter, OJK has regulated in detail the provisions related to Implementation Guidelines to amend clauses in a Standard Agreement.

Based on SACL, Financial Services Business [Pelaku Usaha Jasa Keuangan (PUJK)] are allowed to apply Standard Agreement in entering into the agreement between PUJK and consumers, on condition that the agreement shall by and based on the provisions of SACL. As has been defined by SACL, Standard Agreement means written agreement established unilaterally by the FSB, containing standard clauses about the content, from or means of execution and is used to offer products and/or services to Consumers on a mass scale. ${ }^{6}$

The fact shows that there has been a violation of the inclusion of standard clause. The standard clause established unilaterally by the business actor is often hidden and invisible. PUJK frequently does not explain the benefit, costs and risks of the offered product and/or services as regulated in SACL. ${ }^{7}$ Moreover, the standard clauses contain provisions related to obligations of consumers without explaining the rights of consumers in detail, and impressing to get

6 See General provision of Circular Letter of Financial Services Authority Number 13/SEOJK.07/2014 concerning the Standard Agreement point 1.

See Provision II Standard Clause in Circular Letter of Financial Services Authority Number 13/ SEOJK.07/2014 concerning the Standard Agreement number 2 letter $b$. rid of the obligations of business actors in regards to the products sold, thus when the consumers suffered losses from the products chosen/purchased, they will face difficulties in fighting for their rights due to the standard clause. For example, in sale and purchase agreement, in its invoice written: "goods purchased is not exchangeable/returnable". This clause limits the buyer's right to return the purchased goods. This clause also comprises the limitation of liability burdened by business actor towards consumers. Besides, the position of this clause is hidden with tinier font size, therefore less seeable and complicates consumers to learn and understand the meaning of the standard clause.

The primary possibility of the situation above is that the consumers are no longer a subject of business, but more as an object of business actor to gain abundant benefit, by deceiving consumers through some tricky unethically establishment of business standard agreement and contradict to the law. Therefore, this possibility of consumers' position arises the needs of supervision instrument towards business actors in regards to the establishment and application of standard clauses. In that way thus the rights and interest of consumers would be protected from the abusive power of business actors.

Based on the elaboration above, this research focuses on studying the supervision carried out by BPSK and OJK towards standard clauses. Using the result of this research, effective supervision model of a standard clause is formed to firmly protect the rights and interest of the consumers. 
Therefore, the problem statements of this research are focused on two question: Firstly, how is the effectiveness of standard clause supervision carried out by BPSK and OJK in the context of consumer protection? Secondly, how is the supervision model that effective enough as an instrument to protect the rights and interest of consumers?

\section{METHOD}

This research is socio-legal research, which studies the law with an inter-disciplined approach. The law is regulation related to the standard clause established by business actors and supervision conducted by BPSK and OJK towards standard clause. Interdisciplined approach is laws and regulations approach combined with a sociological approach. Laws and regulation approach are conducted by studying regulations correlates to the legal problem. The sociological approach used to understand legal aspect in society especially related to its function as a tool of social control. In regards to sociological approach, the writer uses economic science namely regulationeconomy.

This research took place in BPSK Office of Yogyakarta, Jakarta and Bandung, also OJK Office Center and in Daerah Istimewa Yogyakarta (DIY), and also Finance and Banking Institutions in Yogyakarta. The required data consist of primary data and secondary data. Primary data are the results of interviews with some informants from BPSK Office, OJK Office and Finance and Banking Institution in DIY. Secondary data comprises primary and secondary legal substance.

\section{RESULTS AND DISCUSSION}

\section{The effectiveness of Standard Clause Supervision carried out by OJK}

To measure the effectiveness of activity of an organization is not easy and simple because effectiveness is analysable from any framework and depends on who assess and interpret the effectiveness. The degree of effectiveness is measurable through comparing the determined and operated plan with the achieved factual result. In case the effort or the result and the action are not correct and causes target unachieved, thus they are not effective.

Based on the library research on effecti-veness theory, the theory shows varied indicators of assessment on effectiveness level of something. This condition sometimes complicates the study in research involving effectiveness theory. However generally, the effectiveness of something can be defined as the success to achieve the target or aim determined. Effectiveness has various kinds; one of them is effectiveness of an organization. The same as effectiveness theory in common, the experts has some viewpoints related to the concept of effectiveness of an organization. ${ }^{8}$

The result of library research correlates with the effectiveness of supervision by OJK on standard clause, by doing necessarily addition and subtraction, the parameter of the effectiveness of supervision on standard clause could be developed. Based on the supervision parameters, either qualitatively

See, Soerjono Soekanto. (1988). Efektivitas Hukum dan Penerapan Sanksi, Bandung: CV. Ramadja Karya. p. 80; Achmad Ali. (2010). Menguak Teori Hukum dan Teori Peradilan Vol.1, Jakarta: Kencana, p. 375; Romli Atmasasmita. (2001). Reformasi Hukum, Hak Asasi Manusia \& Penegakan Hukum. Bandung: Mandar Maju, p. 55. 
Table 1. Index of Effectiveness of Supervision on Standard Clause by OJK

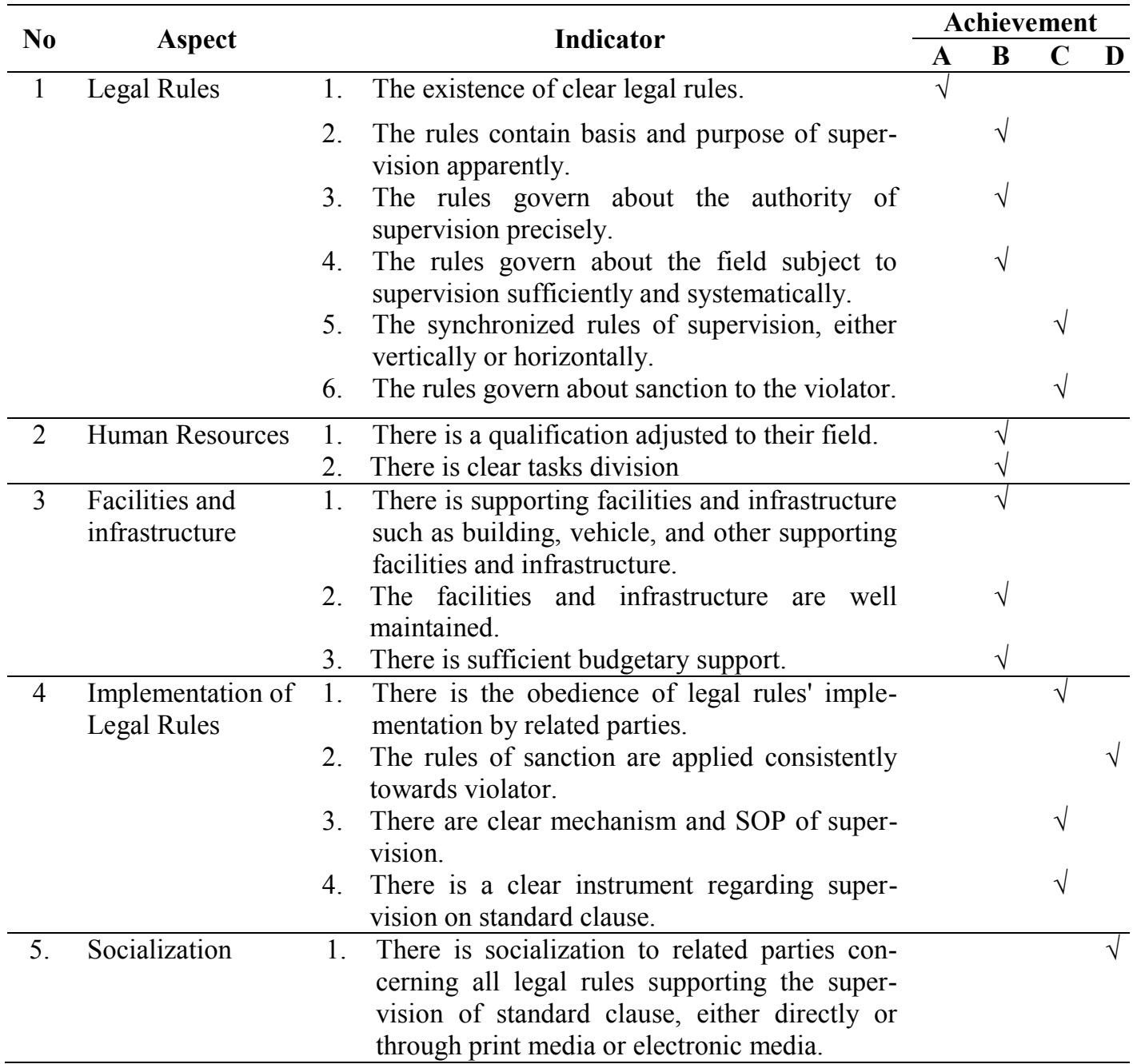

Annotation: A= Very Good (4), B = Good (3), C = Fair (2), D = Poor (1)

Source: Result of primary data processing

or quantitatively, the effectiveness of supervision on a standard clause by OJK is explainable in Table 1.

The value of Index of Effectiveness of Supervision on Standard Clause (IESSC) by OJK in an assumption that $\mathrm{A}=4, \mathrm{~B}=3, \mathrm{C}=2$, and $\mathrm{D}=1$ in distance ratio reduction of 0,25 and the weight of each component is 1 (one) as all parts are critical. The measurement results as follow:

$$
\begin{aligned}
\text { IESSC } & =\frac{(\text { sum amount of value }) \times \text { Weight }}{\text { Total Components }} \\
& =\frac{(17+6+9+9+1) \times 1}{16} \\
& =2.625(\text { Value } \mathrm{B} / \mathrm{C}) \\
& =\text { Fair }
\end{aligned}
$$

Based on the measurement, the supervision on a standard clause by OJK is effective enough.

\section{The Effectiveness of Standard Clause Supervision carried out by BPSK}

Duty and authority of BPSK are regulated under article 52 of Consumer Protection Act jo. the decision of Industrial and Trade Ministry the Republic of Indonesia Number 350/MPP/Kep/12/2001. There are 2 (two) strategic functions of BPSK: (1) As the instrument of Alternative Dispute Resolution, through conciliation, mediation and arbitration, and; (2) do supervision on 
the inclusion of standard clause by business actor, including standard clause in sale and purchase transaction of goods/services conducted by business actors or business entity, either private company or state-owned enterprises.

Under Article 52 letter c, BPSK does has not only duty on alternative dispute resolution, but also responsibility for providing consultation, supervision on standard clause, as a complaint of consumers related to the violation of consumer protection and also other duty and authority concerning the examination of alleged violation of Consumer Protection Act by business actor.

BPSK has dual functions namely judicative and executive. The former means the body has an authority of dispute settlement, and the latter means to supervise the inclusion of standard clause established unilaterally by the business actor. ${ }^{9}$ This multifunction role makes a unique characteristic of BPSK, in one hand has authority as a consultative institution and receive complain, on the other hand, has authority to decide. ${ }^{10}$

The result of the research shows that BPSK is not effectively conducted its duty and function as a standard clause supervision agency. Some causing obstacles are: First, related to budgetary. In this case, BPSK cannot perform its supervision function on a standard clause due to the lack of budgetary support either from central government or

$9 \quad$ Anonym. (2012). Himpunan Peraturan Perlindungan Konsumen Seri Kelembagaan, Direktorat Pemberdayaan Konsumen, Ditjen Standarisasi dan Perlindungan Konsumen Kementrian Perdangangan Republik Indonesia, p. v.

10 Bernadette T. Wulandari. (2006). "Badan Penyelesaian Sengketa Konsumen (BPSK) Sebagai Alternatif Upaya Penegakan Hak Konsumen di Indonesia", Jurnal Gloria Juris, 6(2): 145. local government. The result of research shows almost all BPSK in Indonesia does not receive sufficient budgetary support. ${ }^{11}$ This affects the performance of BPSK to work optimally. In Article 3 of Presidential Decision Number 90 Year 2001 concerning the Establishment of BPSK in 10 (ten) Cities in Indonesia, the cost of BPSK subject to The Local Government Budget (LGB), while each district has a different budget. In fact, the participation of local government in the allocation of budget to BPSK is insignificant. $^{12}$

Second, concerning to institutional facilities. The supervision on a standard clause by BPSK requires some adequate facilities to support the performance of BPSK members in doing their duty and authority in the best way. The result of the research shows that BPSK does not have adequate facility especially in performing its power of supervision on standard clause. So far, the facilities of BPSK are usable only for dispute settlement of the complaint.

Third, related to human resources. The result of the research shows that in general, human resources in BPSK are inadequate. The lack of human resources to perform supervision duty on standard clause caused by the limited number of BPSK members and thus makes the members difficult to focus on two functions at the same time. On the other hand, the number of consumers in Indonesia is proportional to the population in Indonesia, therefore complicate BPSK members to accomplish two functions, dispute settlement, and supervision, at the

\footnotetext{
11 Interview with Djainal Abidin, a member of BPSK RI, Friday 10 June 2016 at 20.00 WIB.

12 Interview with Djainal Abidin, Op.Cit.
} 
same time. In practice, BPSK is only passive and the supervision conducted through nurturing, thus in case a violation of standard clause inclusion occurs, BPSK only order the business actors to exclude the standard clause which causing loss to consumers.

Fourth, in regards to the implementation of regulations. The establishment of Decision of Industrial and Trade Ministry Republic of Indonesia Number 350/MPP/Kep/12/2001 concerning the Duty and Authority of BPSK shall be the guidelines for BPSK to execute its duty and authority. This decision only regulates about the dispute settlement and does not include technical guidance of standard clause supervision function.

This condition becomes an obstacle for BPSK to carry out its duty of standard clause supervision. The result of the research also finds out that there is an overlap of one regulation to another. In Consumer Protection Act, the duty and authority of BPSK are to hear complaints from the consumers, either written or orally, about the violation of consumer protection. However, under the Ministerial Decision above, BPSK has an authority of supervision on standard clause with or without complaint. This means BPSK should perform supervision without any prior complaint from consumers. These vague regulations cause dilemma of BPSK to do its duty and authority.

\section{Effective Model of Supervision of Standard Clause}

Based on the result of the research, then a kind of effective model of supervision on a standard clause is being formed as an instrument for consumer protection. This supervision model is based on several preconditions such as: (1) the needs of institution/ agency reformation whom authorized to do supervision of standard clause; (2) the needs to determine the scope of duty and authority of standard clause supervision institution; (3) the needs of determination of material range about standard clause subjected to supervision which comprises: the content, the form, the position and the disclosure; (4) the needs of clear mechanism of standard clause supervision conducted by supervision institution; (5) the needs of following up the supervision results, especially to the business actors who break the standard clause rules.

The explanation would be as follow: First, based on the result of the research, it is found dualism of institution that authorized to do supervision of standard clause, namely OJK and BPSK. In the field of finance and banking, the supervision of standard clause carried out by OJK, while other than that would be conducted by BPSK. The legal basis of OJK to do supervision of standard clause is Article 21 and 22 of Financial Services Authority Act and Implementing Regulation of Financial Services Authority Number 1 Year 2013 and Circular Letter Number 13/SEOJK.07/2014. Meanwhile, the legal basis of BPSK authority of standard clause supervision is Article 52 of Consumer Protection Act.

Even though normatively, the legal basis of duty and authority of both institutions is definite and compelling such as Financial Services Authority Act and Consumer Protection Act, empirically performance of both institutions' duty and authority is not effective. Essentially in 
undertaking the supervision of standard clause, OJK merely do "filing" and has not arranged a comprehensive system to conduct supervision of standard clause. On the other side, BPSK also does not perform its duty and authority of supervision of standard clause at all.

The result of this research shows that it is important to establish a new supervisory body of a standard clause that is effective, independent, and no dualism in doing supervision; therefore, consumers will obtain satisfactory protection related to the establishment of a standard clause. After carrying out an institutional study in regards to the duty and authority, the most precise institution to perform supervision of standard clause is National Consumer Protection Body [Badan Perlindungan Konsumen Nasional (BKPN)].

Second, the research of supervisory body of a standard clause produces the arrangement of the scope of duty and authority. The authorities of supervisory body are outlined as follow: (1) establish regulation related to standard clause; (2) ask for periodic report to business actor who establish standard clause in the form of implementation report of establishment and accomplishment phase of standard clause based on the laws; (3) carry out supervision directly/straight audit. This authorization aimed to enable the supervisory body to objectively control business actor; (4) organize preliminary inquiries of standard agreement containing criminal law violation clause, then recommend/report to police for investigation process; (5) determine/arrange the standard model of standard agreement that shall be obeyed by business actor, based on the agreement of consumer through Non-Governmental Consumer Protection Institution [Lembaga Perlindungan Konsumen Swadaya Masyarakat (LPKSM)], Government, Business Actor, Expert; (6) study and recommend to government in regards to the kinds of standard clause feasible to causing loss for consumer and also recommend to impose the sanction for business actor violating establishment and accomplishment of standard agreement based on ministerial regulation; (7) annul standard clause which harm consumers massively. Due to the standard agreement is established and applicable massively in society, thus if a standard agreement harms one consumer, then this agreement presumed to cause detriment to other consumers.

The duties of supervisory body of standard clause in detail are as follow: (1) ask for periodic report to business actor who establish standard clause in the form of implementation report of establishment and implementation phase of standard clause based on the laws and also collect/review the report concerning the procedure of establishment of agreement, the implementation of contract either distributed or undistributed; (2) carry out supervision directly/straight audit; (3) organize preliminary inquiries of standard agreement containing criminal law violation clause, then recommend/report to police for further investigation process; (4) study and recommend to government in regards to the kinds of standard clause feasible to harm consumer and also recommend to impose sanction for business actor violating 
the establishment and accomplishment of standard agreement based on ministerial regulation; (5) establish particular body who has duty to do juridical review of standard agreement which contradict to the laws and regulations, this special body shall be integrated to judiciary and government in order to terminate the standard agreement massively on the ground of consumer and business legal protection; (6) carry out coordination and monitoring actively to supervisory body in the scope of services business or finance services such as OJK, $\mathrm{BI}$ and related ministerial offices, in order to gain information and coordination to perform supervision of standard agreement (integrated supervision).

Third, the restriction of subject matter in certain standard clause shall thoroughly refer to article 18 of Consumer Protection Act. Concerning with the structure, the standard clause shall be expressed in written or digitally then confirmed by the signature of both parties, and feasibly inserted to print or electronic media. Therefore, both parties may generously learn the purpose and the objectives of the agreement as the agreement have legal binding force due to the signature of both parties. Instead of expressed in written form, the position of standard clause shall be in a strategic place, noticeable by reader such as in the bottom of agreement/invoice, etc and complete with the punctuation “...", bold, italic, with bigger font size or in minimum standard (12), thus visible to the readers and understandable by consumers.

Fourth, the expression of a standard clause shall refer to the Circular Letter established by Financial Services Authority. The essential points are: (1) the standard clause containing rights and duty of consumers and binding requirements to consumers shall use legible letter, writing, symbol, diagram, logo, term or phrase, and/ or use the understandable simple sentence in Indonesian language to consumers; (2) should the consumers find any obscurity, business actor shall explain the term, phrase, sentence and/or symbol, diagram and other sign that the consumer has not understood yet, either written in the standard agreement, or orally prior to the signature of standard agreement; (3) in case the term, phrase and/ or the sentence of standard clause expressed in language other than Indonesian language, then the term, phrase and/or the sentence shall have its subtitle in Indonesian and put next to the initial one; (4) the standard clause shall contain this sentence, "IN ACCORDANCE TO THE PROVISIONS UNDER LAWS AND REGULATIONS"; (5) when the standard clause is printed, then the following condition shall apply: (a) business shall make sure the written approval of consumers by their initial signature in the standard agreement or other documents ascribed to the Standard Agreement containing consumers' approval; and (b) business may copy the file so that the transaction may achieve its goal, rapid, effective, efficient, recurrence, and grant legal certainty.

Fifth, the mechanism of supervision of applicable standard clause and established by business is not simple, considering the lots of industrial sectors, business in finance or non-finance services requiring standard agreement in their daily transaction. 
Following the research of supervision mechanism of a standard clause, there shall be two kinds of supervision mechanism; those are (1) pre-contract mechanism; (2) post-contract (the implementation of contract) mechanism.

In the pre-contract mechanism, the supervisor shall review and examine all standard agreement before its establishment and approval from consumers, whether the agreement has in accordance to the standard under the laws and regulation; the agreement might be applicable once there has been a verification mark from a supervisory body. If business actors do not comply with this mechanism, they might be apprehended during the post-contract mechanism. In the post contract mechanism, the supervisory body would be more passive and wait for complaints from society, and then followed up by thematic inquiry based on complaint and report from the consumers. ${ }^{13}$ Therefore, a supervisory body is liable to the consumers' awareness by establishing socialization to society concerning the fair standard agreement. This kind of supervision would be effective if the supervisor has authority to impose administration sanction from the lower to the higher one.

Follow-up of the supervision is a significant action. This is an output of the supervision process, and also the followup may constitute parameter of success over the supervision itself. Therefore, the researcher arrange a follow-up of supervision as follow: (1) the problematic standard agreement shall be examined and

13 Subir Kumar Roy. (2016). "Consumer Justice: A Symbol of Economic Prosperity and Social Progressiveness". Hasanudin Law Review, 2(2): 182-194. classified based on its problem, then propose for thorough annulment; (2) towards the standard agreement containing criminal action, there shall be preliminary inquiry and recommend for investigation to the police; (3) the impose of sanction to the business actor violating the rules, and coordinate to other intern body/institution/minister (i.e. related finance services institution the impose of sanction shall coordinate to OJK, therapeutic agreement shall coordinate with Minister of Health): (a) oral warning; (b) written notice; (c) administration sanction; (d) fine; (4) towards complaint from society, the thematic surveillance (post-supervision) shall be taken into account, and in case the violations are found, then the violations are classified and followed up by the steps above (1), (2), (3), and (4). For the government institution that proven participates in doing violation would be recommended to the related government/minister. Based on the finding of this research, the model of a standard clause supervision is charted as below:

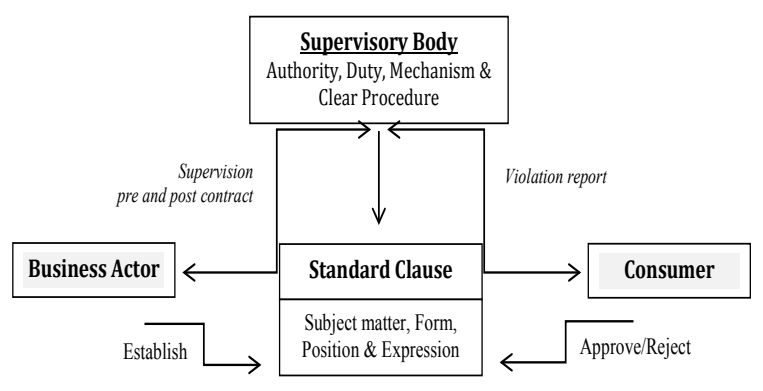

Scheme of Effective Model of Standard Clause Supervision

\section{CONCLUSION}

The legal basis to regulate standard clause supervision is Circular Letter established by OJK. This condition demonstrates juridical weakness due to Circular Letter is not the part 
of binding rules as determined by Act Number 12 of 2011 concerning the Establishment of Laws and Regulations. Second, OJK does not execute supervision during the precontract phase, when the standard clause is about to established. In doing supervision during the pre-contract stage, OJK only uses one mechanism of sampling towards certain problematic Financial Service Institution. In pre-contract stage, OJK is passive and wait for a report from PUJK and dispute report from consumers; thus, consumers shall be active and recognize the details of the chosen financial services products. Third, business actors have not received information about a standard clause that violates the law. This condition occurs due to the lack of and minimum socialization conducted by OJK.

The supervision of standard clause by BPSK is also ineffective or even unimplemented at all. This circumstance happen due to numbers of obstacles in BPSK itself, that is: (1) lack clear procedure from BPSK in conducting supervision of standard clause, and thus raises uncertainty; (2) minimum numbers of human resources to support the supervision in BPSK; (3) minimum budget to support the performance of BPSK; (4) For now on, BPSK focuses only on consumers dispute settlement, not as supervisory body, therefore BPSK is overwhelmed in doing supervision; (5) minimum facilities and infrastructures to do supervision.

Finally, the result of this research is built an effective model of supervision on standard clause is being formed as an instrument for consumer protection in the bussines transactions. This supervision model is based on several preconditions such as: (1) the needs of institution/ agency reformation whom authorized to do supervision of standard clause; (2) the needs to determine the scope of duty and authority of standard clause supervision institution; (3) the needs of determination of material scope about standard clause subjected to supervision which comprises: the content, the form, the position and the disclosure; (4) the needs of precise mechanism of standard clause supervision conducted by supervision institution; (5) the needs of following up the supervision results, especially to the business actors who break the standard clause rules.

\section{Acknowledgment}

Authors would like to express gratitude to Director of Research and Social Service Institute of Universitas Islam Indonesia (UII) Yogyakarta who has granted excellence research fund for higher education that supported the creation of the research and this article.

\section{BIBLIOGRAPHY}

Achmad Ali. (2010). Menguak Teori Hukum dan Teori Peradilan. Vol. 1, Jakarta: Kencana.

Bernadette T. Wulandari. (2006). "Badan Penyelesaian Sengketa Konsumen (BPSK) Sebagai Alternatif Upaya Penegakan Hak Konsumen di Indonesia”, Jurnal Gloria Juris, 6(2): 145.

Circular Letter of Financial Services Authority Republic of Indonesia Number 13/SEOJK.07/2014 concerning Standard Agreement.

David M.L. Tobing. (2015). Klausula 
Baku: Paradoks dalam Penegakan Hukum Perlindungan Konsumen. (Dissertation). Jakarta: Postgraduate School, Universitas Indonesia.

Decision of Industrial and Trade Ministry of Republic of Indonesia Number 350/ MPP/Kep/12/2001

Inda Rahardyan. (2014). Hukum Pasar Modal Indonesia. Pengawasan Pasar Modal Pasca Terbentuknya Otoritas Jasa Keuangan. Yogyakarta: UII Press. Regulation of Financial Services Authority Republic of Indonesia Number 1/ POJK.07/2013 concerning the Consumer Protection of Financial Services.

Regulation of Minister of Domestic Affair of Republic Indonesia Number 55
Year 2010 concerning Official Scripts in Ministerial of Domestic Affairs Environment.

Romli Atmasasmita. (2001). Reformasi Hukum, Hak Asasi Manusia \& Penegakan Hukum. Bandung: Mandar Maju.

Soerjono Soekanto. (1988). Efektivitas Hukum dan Penerapan Sanksi, Bandung: CV. Ramadja Karya.

Subir Kumar Roy. (2016). “ConsumerJustice: A Symbol of Economic Prosperity and Social Progressiveness". Hasanudin Law Review, 2(2): 182-194.

Susanti Adi Nugroho. (2011). Proses Penyelesaian Sengketa Konsumen Ditinjau dari Hukum Acara serta Kendala Implementasinya. Jakarta: Kencana. 